\title{
Isolation and Characterization of Atrazine-Degrading Xanthomonas sp. ARB2 and Its Use in Bioremediation of Contaminated Soils
}

\author{
Sopid Sawangjit
}

\begin{abstract}
Thai degrading-bacteria, strain ARB2, was isolated from sugarcane field soils in Ratchaburi province of Thailand. Strain ARB2 was gram-negative bacteria, rod shape in pair and a single cell. The genomic DNA was extracted following the standard protocol for bacterial genomic DNA preparations. The partial 16S rDNA genes were amplified by polymerase chain reaction (PCR) using the universal primers of 16S rDNA gene. Sequence analysis of the PCR product indicated that the 16S rRNA gene in strain ARB2 was ranging from $89-91 \%$ identical to the same region in Xanthomonas sp. and were named Xanthomonas sp. ARB2. Xanthomonas sp. ARB2 was capable of degrading $300 \mathrm{mg} \mathrm{L}^{-1}$ and $100 \mathrm{mg} \mathrm{kg}^{-1}$ of atrazine in mineral salts liquid medium and soil at $81 \%$ and $62 \%$ in 7 days, respectively. GC-MS analysis detected the formation of two metabolites, deethylatrazine (DEA) and deisopropylatrazine (DIA) during the process of degradation of atrazine.
\end{abstract}

Index Terms-Atrazine, biodegradation, bioremediation, contaminated soil.

\section{INTRODUCTION}

Atrazine (2-chloro-4-(ethylamino)-6-(isopropylamino) -1, 3,5 -triazine) is a selective, systemic triazine herbicide, widely used for the control of annual broadleaf and grassy weeds in corn, maize and sugarcane. Although banned for use in many European countries, atrazine is still a commonly used herbicide in many countries like China, India and USA [1], [2]. In states with high atrazine use, surface and ground water commonly have detectable levels of atrazine [3], [4]. Atrazine persists in soil and ground water and has the potential to leach into drinking water supplies [5]. One result of this concern is that research has increased on microorganisms found in atrazine-impacted areas, as atrazine dissipation is often accelerated after continued exposure to the herbicide [6]-[8].

Microbial degradation has been regarded as the primary mechanism of atrazine degradation in contaminated sites [9]. Bioremediation, the use of microorganisms to clean up contaminated site, is an environmentally safe solution for atrazine removal [10], [11]. Up to date, a number of atrazine-degrading strains from different bacterial genera have been isolated. Atrazine can be degraded by Arthrobacter

Manuscript received May 1, 2015; revised July 16, 2015. This work was supported by Institute for Research and Development, Suan Sunandha Rajabhat University, Thailand.

Sopid Sawangjit is with the Department of Biotechnology, Faculty of Science and Technology, Suan Sunandha Rajabhat University, Bangkok, CO 13000, Thailand (e-mail: sopid.sa@ssru.ac.th, sawangjit.s@hotmail.com). sp. [12], Chelatobacter heintzii [13], Rhodococcus sp., Acinetobacter sp., Streptomyces sp., Pseudomonas aeruginosa, Clavibacter michiganense [14], Enterobacter cloacae [15], Bacillus megaterium, Alcaligenes faecalis, Klebsiella ornithinolytica, and Agrobacterium tumefaciens [16]. Under aerobic conditions, Rhodococcus strain TE1 can metabolize the atrazine into deethylatrazine (DEA) and deisopropylatrazine (DIA) [17]. Pseudomonas strain ADP metabolizes atrazine into cyanuric acid via three enzymatic steps, encoded by the genes atzABC [18] and cyanuric acid acts as a nitrogen source for many bacteria.

In Thailand, a number of atrazine-degrading bacterial strains, belonging to diverse genera, have been isolated and characterized for research and bioremediation purposes. These include strains of Klebsiella, Rhizobium and Stenotrophomonas [19], [20].

This study aims to isolate and investigate atrazine-degrading bacteria from agricultural soil samples in Ratchaburi province. Once atrazine-degrading bacteria were isolated, we sequenced their 16S rRNA genes and compared with previously reported bacteria. Experiments were conducted to determine the bioremediation capacity of atrazine contaminated in culture and in soils.

\section{MATERIALS AND METHODS}

\section{A. Chemicals and Media}

Atrazine (98.9\% purity) was purchased from Chem Service Inc. (West Chester, PA, USA). Enrichment medium consisted of a mineral salts medium (MSM) and $100 \mathrm{mg} \mathrm{L}^{-1}$ atrazine as the sole nitrogen source, plus sucrose $3 \mathrm{~g} \mathrm{~L}^{-1}$ as carbon source, and was autoclaved at $121{ }^{\circ} \mathrm{C}$ for 30 minutes. The mineral salts medium (MSM) contained (per liter) $1.6 \mathrm{~g}$ of $\mathrm{K}_{2} \mathrm{HPO}_{4}$, $0.40 \mathrm{~g}$ of $\mathrm{KH}_{2} \mathrm{PO}_{4}, 0.20 \mathrm{~g}$ of $\mathrm{MgSO}_{4} \cdot 7 \mathrm{H}_{2} \mathrm{O}$ and $0.10 \mathrm{~g}$ of $\mathrm{NaCl}$ [21]. Trace element solution contained (per liter): EDTA, 2.5 $\mathrm{g} ; \mathrm{FeSO}_{4} \cdot 7 \mathrm{H}_{2} \mathrm{O}, 1.0 \mathrm{~g} ; \mathrm{ZnSO}_{4} \cdot 7 \mathrm{H}_{2} \mathrm{O}, 5.0 \mathrm{~g} ; \mathrm{MnSO}_{4} \cdot \mathrm{H}_{2} \mathrm{O}, 1.0$ g; $\quad \mathrm{CuSO}_{4} \cdot 5 \mathrm{H}_{2} \mathrm{O}, \quad 0.40 \mathrm{~g} ; \quad \mathrm{Na}_{2} \mathrm{~B}_{4} \mathrm{O}_{7} \cdot 10 \mathrm{H}_{2} \mathrm{O}, \quad 0.20 \mathrm{~g}$; $\mathrm{Na}_{2} \mathrm{MoO}_{4} \cdot 2 \mathrm{H}_{2} \mathrm{O}, 0.25 \mathrm{~g}$. The $\mathrm{pH}$ of the medium was adjusted to 7.0 with $1 \mathrm{M} \mathrm{NaOH}$ solution. For solid medium, $2 \%(\mathrm{w} / \mathrm{v})$ agar was added to the same atrazine containing liquid mineral salts medium.

\section{B. Enrichment and Isolation}

The soil samples were collected from an agricultural field cultivated with sugarcane in Ratchaburi province, Thailand The soil samples were collected from 0 to $15 \mathrm{~cm}$ of soil depth with a hand-driven soil auger and stored at $4{ }^{\circ} \mathrm{C}$ until they were used. Soil samples $(10 \mathrm{~g})$ were suspended in $30 \mathrm{ml}$ of 0.1 
M phosphate buffer $(\mathrm{pH}=7.5)$ and centrifuged at $6000 \times \mathrm{g}$ for 15 min at $4{ }^{\circ} \mathrm{C}$ and the supernatants were discarded to remove the quantity of residual nitrogen sources in soil [22].

Enrichment of the atrazine-degrading microorganism was performed in $100 \mathrm{ml} \mathrm{MSM} \mathrm{supplemented} \mathrm{with} 2.5 \mathrm{mg} \mathrm{L}^{-1}$ of atrazine [23] as the sole carbon and nitrogen source from the $10 \mathrm{~g}$ soil sample and incubated aerobically by shaking at 150 rpm at $37{ }^{\circ} \mathrm{C}$ for 7 days. All enrichment cultures were subcultured on the same medium at 7 day interval for a total of three passes. The final culture was diluted and plated on MSM agar plates containing atrazine $\left(300 \mathrm{mg} \mathrm{L}^{-1}\right)$. Developed colonies were repeatedly streaked on atrazine agar plates for isolation of a pure culture. Colonies which developed cleared zones in the atrazine-containing MSM agar were purified and routinely maintained on this medium. A bacterial isolate, designated strain ARB2, was selected for Gram staining and further studies.

\section{Identification of Strain ARB2 by $16 S$ rDNA Sequence}

The genomic DNA of the strains was extracted and precipitated following the standard protocol for bacterial genomic DNA preparations [24]. The primer pairs of 27F (5'AGAGTTTGATCMTGGCTCAG -3') and 1492R (5'TACGGHTACCTTGTTACGACTT -3') were used for amplification of $16 \mathrm{~S}$ rDNA of ARB2, and the product was approximately $1400 \mathrm{bp}$. Reactions were carried out in $25 \mu \mathrm{L}$ volumes containing $5 \mu \mathrm{L}$ of template DNA, $2.5 \mu \mathrm{L}$ of $10 \mathrm{X}$ PCR buffer $(0.5 \mathrm{M} \mathrm{KCl}, 0.1 \mathrm{M}$ Tris- $\mathrm{HCl}, \mathrm{pH} 9.0$ and $1 \%$ Triton X-100), $2.0 \mu \mathrm{L}$ of $25 \mathrm{mM} \mathrm{MgCl} 2,0.5 \mu \mathrm{L}$ of $10 \mathrm{mM}$ deoxyribonucleoside triphosphate, $1.0 \mu \mathrm{L}$ of $10.0 \mu \mathrm{M}$ of each primer, and $0.1 \mu \mathrm{L}$ of $5 \mathrm{U}$ Taq polymerase. The cycles used were as follows: 1 cycle at $94{ }^{\circ} \mathrm{C}$ for $5 \mathrm{~min} ; 35$ cycles at $94{ }^{\circ} \mathrm{C}$ for $60 \mathrm{~s}, 55^{\circ} \mathrm{C}$ for $60 \mathrm{~s}, 72{ }^{\circ} \mathrm{C}$ for $120 \mathrm{~s}$; and 1 cycle of $72{ }^{\circ} \mathrm{C}$ for $15 \mathrm{~min}$. Sequencing of the $16 \mathrm{~S}$ rDNA was performed by First BASE Laboratories Sdn Bhd., Malaysia. The DNA sequences were analyzed using the BLAST program of the National Centre for Biotechnology. Sequences were analyzed and concatenated by using DNASTAR (DNASTAR, Inc., Madison, Wis.) A multiple-sequence alignment was prepared by using CLUSTAL W [25], and phylogenetic trees were constructed by using the neighbor-joining method.

\section{Degradation of Atrazine by Isolate ARB2}

Strain ARB2 was incubated in MSM with $100 \mathrm{mg} \mathrm{L}^{-1}$ of atrazine as carbon and nitrogen source. ARB2 fresh cell suspension $\left(\mathrm{OD}_{600}=0.8\right)$ was incubated aerobically with shaking $(150 \mathrm{rpm})$ at $37{ }^{\circ} \mathrm{C}$ in sterile flask $(250 \mathrm{~mL})$ containing $100 \mathrm{~mL}$ of the liquid medium supplemented with $300 \mathrm{mg} \mathrm{L}^{-1}$ of atrazine. The medium without inoculation of isolated strain was used to confirm the biodegradation mechanism. All these tests were performed in triplicate. The changes of atrazine concentrations in the liquids were monitored by high performance liquid chromatography (HPLC) analysis [26]. The samples were collected at the incubation time of $0,1,3,5$ and 7-day and analyzed to determine the remained atrazine concentration at each time interval.

\section{E. Bioremediation of Atrazine-Contaminated Soil}

Soil samples (1 kg) were sterilized by autoclave. Subsamples (25 g) of autoclaved, $2.5 \mathrm{mg}$ of atrazine (100 ppm), $1 \mathrm{~mL}$ of mineral salts liquid medium, and $1 \mathrm{~mL}$ of ARB2 liquid culture were mixed in sterile Petri dishes and incubated at $37^{\circ} \mathrm{C}$. Negative control contained no live cells. The soil was kept damp by spraying with sterilized water daily. Three dishes from each treatment were removed on day $0,1,2$, 3,5 and 7 , and analyzed to determine the remained atrazine concentration at each time interval.

\section{RESULTS AND DISCUSSIONS}

\section{A. Isolation of Atrazine-Degrading Bacteria by Enrichment}

An atrazine-degrading bacterium, designated strain ARB2, was isolated from an agricultural soil. The pure cultures were gram-strained and a phylogenetic analysis of their $16 \mathrm{~S}$ rRNA gene sequences was performed. Morphological characterization indicated that ARB2 was a Gram-negative bacteria, rod shape in pair and a single cell. The $16 \mathrm{~S}$ rRNA sequence of strain ARB2 was compared to those of the bacterial sequences in GenBank. Nucleotide sequences of $16 \mathrm{~S}$ rRNA gene of ARB2 were closely related to those of Xanthomonas sp. FSBSY16, Xanthomonas sp. QSt2, Xanthomonas sp. FSGSD7 and Xanthomonas sp. CU12 with nucleotide sequence identity ranging from $89 \%$ to $91 \%$. Fig. 1 shows that strain ARB2 formed a closely related group with many Xanthomonas sp. strain such as FSBSY16, QSt2, FSGSD7 and CU12 and showed a greater sequence homology among them than with other Xanthomonas theicola, Xanthomonas melonis and Xanthomonas albilineans, whereas genus Pseudoxanthomonas, Lysobacter, Bacillus and Arthrobacter were clearly separated to the other clades. Based on morphological characterization, sequence comparisons and phylogenetic analyses, strain ARB2 was identified as new strain of Xanthomonas and named Xanthomonas sp. ARB2. Further characterization of this strain may lead to a better affiliation in the future.

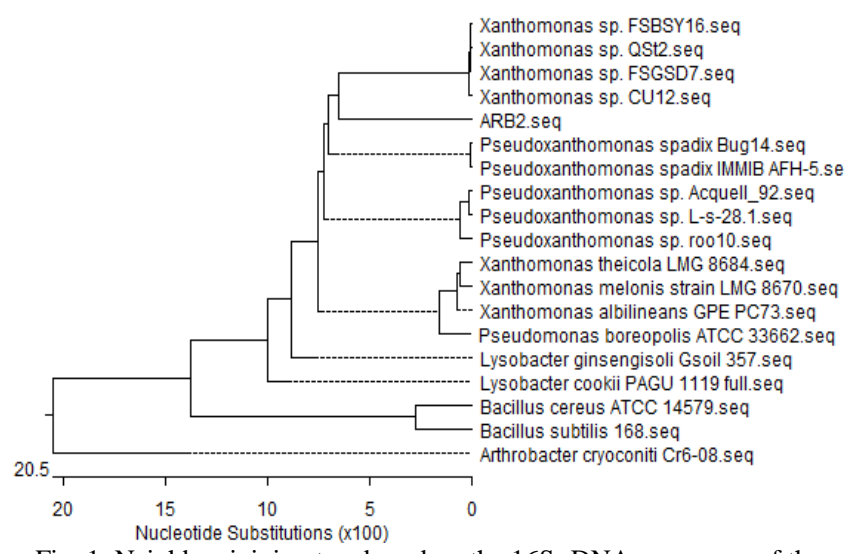

Fig. 1. Neighbor-joining tree based on the 16S rDNA sequences of the atrazine-degrading isolates (ARB2) with related $16 \mathrm{~S}$ rDNA sequences found in GenBank database.

\section{B. Degrading Ability of Xanthomonas Strain ARB2}

Atrazine degradation by strain ARB2 was performed thrice in bacterial medium containing atrazine of $300 \mathrm{mg} \mathrm{L}^{-1}$. At $37^{\circ} \mathrm{C}$, atrazine degradation in media containing atrazine as sole carbon and nitrogen source showed the maximum degradation of $81.7 \%$ in 7 days of incubation (Fig. 2), 
whereas the loss of atrazine in uninoculated, sterile controls was not evident. Atrazine was rapidly degraded by ARB2 and it produced the metabolites. The Gas chromatography-mass spectrometry (GC-MS) analysis revealed that the metabolites produced by the isolate during atrazine degradation were deethylatrazine (DEA) and deisopropylatrazine (DIA) (Fig. 3).

\section{Bioremediation of Atrazine-Contaminated Soil}

The reduction in atrazine concentration during the biodegradation assay is shown in Fig. 4. Atrazine biodegradation rates were significantly enhanced in the inoculated soils as compared to uninoculated control soils. Degradation of atrazine in control autoclaved soils (without inoculation) was minimal where less than $2.2 \%$ of the applied concentration was degraded in 7-day incubation studies. On day 0 , the degradation rates of atrazine in soil inoculated with ARB2 was low (below 0.1\%). After 1, 3, 5 and 7 days, ARB2 removed atrazine $13 \%, 25 \%, 41 \%$ and $62 \%$, respectively. The metabolites produced by ARB2 during atrazine degradation were DEA and DIA (Fig. 5). Whereas the compounds DIA and DIA were not detected in uninoculated soil.

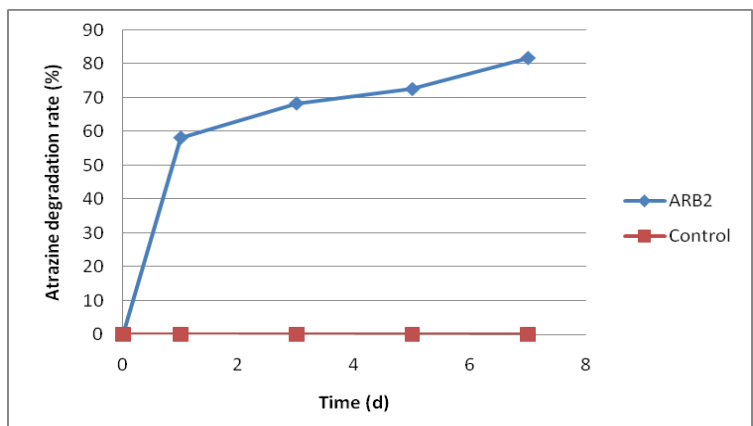

Fig. 2. Biodegradation rate of atrazine by strain ARB2 in liquid medium.

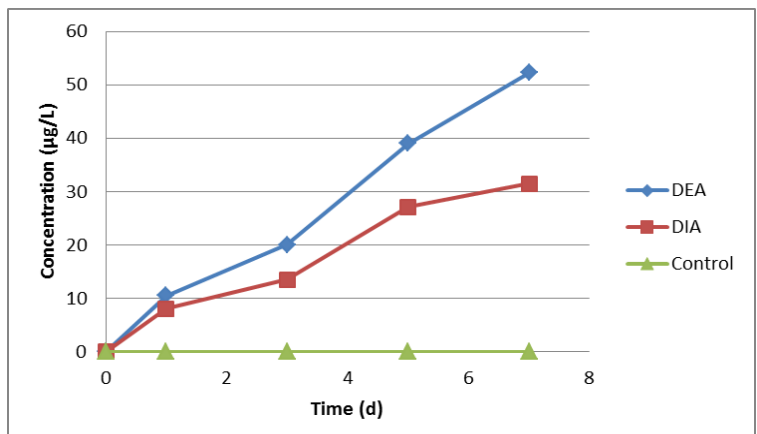

Fig. 3. Degradation metabolites deethylatrazine (DEA) and deisopropyl atrazine (DIA) in the spent atrazine mineral salts medium produced by the isolates ARB2.

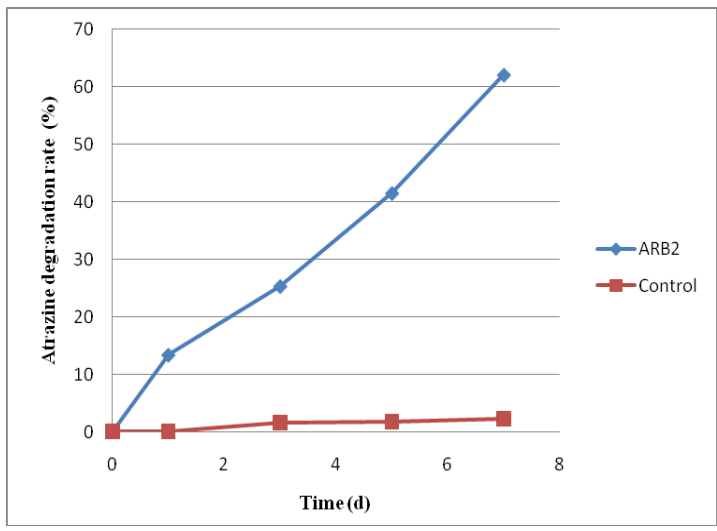

Fig. 4. Biodegradation rate of atrazine by strain ARB2 in soil.

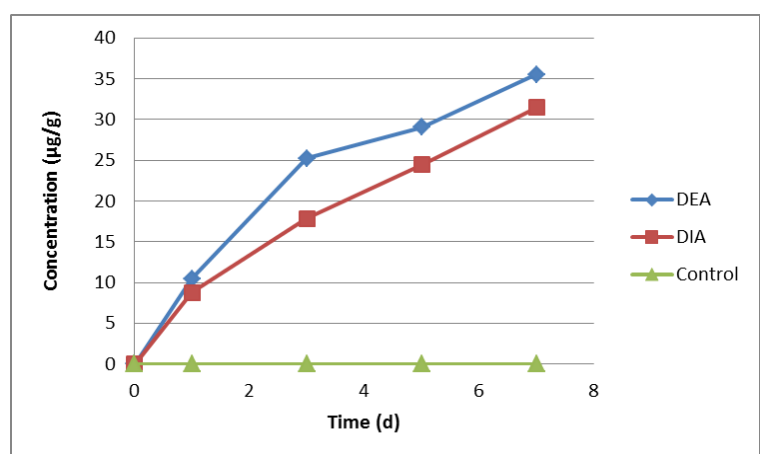

Fig. 5. Degradation metabolites deethylatrazine (DEA) and deisopropyl atrazine (DIA) in soil produced by the isolates ARB2.

\section{CONCLUSIONS}

From the presented results, we were successful in isolating new strain of atrazine-degrading microorganism from a Central Thai agricultural soil, ARB2, gram-negative and short rod which were able to use this herbicide as a sole source of nitrogen. The 16S rDNA nucleotide sequence of strain ARB2 exhibited a 89-91\% nucleotide identity with Xanthomonas $s p$. This isolates studied were grouped with microorganisms in the genera Xanthomonas and named Xanthomonas sp. ARB2.

Strain ARB2 was shown to be capable of removing $81 \%$ and $62 \%$ atrazine in a mineral salts liquid medium and contaminated soil, respectively. The Xanthomonas sp. ARB2 generated deethylatrazine (DEA) and deisopropylatrazine (DIA) by $\mathrm{N}$-dealkylation in the upper degradation pathway. The present knowledge concerning the degradation of atrazine using bacteria species may be relevant for the development of effective bioremediation strategies for contaminated agricultural water and soil.

\section{ACKNOWLEDGMENT}

This work was supported by grants from Institute for Research and Development, Suan Sunandha Rajabhat University, Thailand. The authors wish to gratefully acknowledge the facilities and equipment supports from the Department of Biotechnology, Faculty of Science, Suan Sunandha Rajabhat University, Bangkok.

\section{REFERENCES}

[1] J. A. Erick, B. S. Mackay, E. T. Shane, and E. S. Eric, "Removal of atrazine from water using covalent sequestration," J Agric Food Chem, vol. 52, no. 3, pp. 545-549, Jan. 2004.

[2] K. M. Elsabawy and M. S. Refat, "Modeling, synthesis and application of highly performance nano-surface catalysts towards degradation of some organic pollutants and heavy metals capture from industrial water drains," J Comput Method Mol Design, vol. 1, no. 4, pp. 1-13, 2011.

[3] W. W. Mulbry, H. Zhu, S. M. Nour, and E. Topp, "The triazine hydrolase gene $\operatorname{trz} N$ from Nocardioides sp. strain C190: Cloning and construction of genespecific primers," FEMS Microbiology Letters, vol. 206, pp. 75-79, Jan. 2002

[4] E. I. Solomon, U. M. Sundaraman, and T. E. Machonkin, "Multicopper oxidases and oxygenases," Chem. Rev, vol. 96, no. 7, pp. 2563-2605, Nov. 1996.

[5] S. K. Widmer and R. F. Spalding, "Assessment of herbicide transport and persistence in groundwater: a review," Herbicide Metabolites in Surface Water and Groundwater, vol. 630, Washington, DC: American Chemical Society, 1996, pp. 271-287.

[6] T. K. Ralebitso, E. Senior, and H. W. V. Verseveld, "Microbial aspects of atrazine degradation in natural environments," Biodegradation, vol. 13, no. 1, pp. 11-19, 2002. 
[7] E. Topp, D. W. Gutzman, B. Bourgoin, J. Millette, and D. S. Gamble, "Rapid mineralization of the herbicide atrazine in alluvial sediments and enrichment cultures," Environ Toxicol Chem, vol. 14, no. 5, pp. 743-747, May 1995.

[8] J. A. V. Heyden, T. J. Zethof, and B. Olivier, "Stress-induced hyperthermia in singly housed mice," Physiology and Behavior, vol. 62, no. 3, pp. 463-470, Sep. 1997.

[9] Y. Zhang, Z. Jiang, B. Cao, M. Hu, Z. G. Wang, and X. N. Dong, "Metabolic ability and gene characteristics of Arthrobactersp strain DNS10, the sole atrazinedegrading strain in a consortium isolated from black soil," International Biodeterioration \& Biodegradation, vol. 65 , pp. 1140-1144, 2011

[10] L. P. Wackett, M. J. Sadowsky, B. Martı'nez, and N. Shapir, "Biodegradation of atrazine and related s-triazine compounds: From enzymes to field studies," Appl Microbiol Biotechnol, vol. 58, pp. 39-45, Jan. 2002.

[11] X. Li, H. Zhang, M. Wu, Z. Su, and C. Zhang, "Impact of acetochlor on ammonia-oxidizing bacteria in microcosm soils," J Environ Sci, vol. 20, no. 9, pp. 1126-1131, 2008.

[12] Q. Wang and S. Xie, "Isolation and characterization of a high-efficiency soil atrazine-degrading Arthrobactersp. strain," Int. Biodeter. Biodegr., vol. 71, pp. 61-66, 2012.

[13] S. Rousseaux, A. Hartmann, and G. Soulas, "Isolation and characterisation of new Gram-negative and gram-positive atrazine degrading bacteria from different French soils," FEMS Microbiol. Ecol., vol. 36, no. 2-3, pp. 211-222, 2001.

[14] V. H. Popov, P. S. Cornish, K. Sultana, and E. C. Morris, "Atrazine degradation in soils: The role of microbial communities, atrazine application history, and soil carbon," Soil Res., vol. 43, no. 7, pp. 861-871, 2005

[15] N. Shapir, G. Cheng, M. J. Sadowsky, and L. P. Wackett, "Purification and characterization of TrzF: Biuret hydrolysis by allophanate hydrolase supports growth," Appl. Environ. Microbiol., vol. 72, no. 4, pp. 2491-2495, 2006.

[16] S. Siripattanakul, W. Wirojanagud, J. McEvoy, T. Limpiyakorn, and E. Khan, "Atrazine degradation by stable mixed cultures enriched from agricultural soil and their characterization," J. Appl. Microbiol., vol. 106, no. 3, pp. 986-992, 2009.

[17] R. Behki, E. Topp, W. Dick, and P. Germon, "Metabolism of the herbicide atrazine by Rhodococcus strains," Appl. Environ. Microbiol. vol. 59, no. 6, pp. 1955-1959, 1993.

[18] M. L. Souza, D. Newcombe, S. Alvey, D. E. Crowley, A. Hay, M. J. Sadowsky, and L. P. Wackett, "Molecular basis of a bacterial consortium: Interspecies catabolism of atrazine," Appl. Environ. Microbiol., vol. 64, no. 1, pp. 178-184, 1998.
[19] S. Sopid, "Characterization of novel atrazine-degrading Klebsiella sp. isolated from Thai agricultural soil," in Proc. ICEBESE 2012: International Conference on Environmental, Biological and Ecological Sciences, and Engineering, Paris, 2012, pp. 1400-1402.

[20] S. Sopid, "Phylogenetic characterization of atrazine-degrading bacteria isolated from agricultural soil in Eastern Thailand," International Journal of Biological, Food, Veterinary and Agricultural Engineering, vol. 8, no. 8, pp. 869-872, 2014.

[21] S. P. Lapage, J. E. Shelton, and T. G. Mitchell, "Nutrient agar," Methods Microbiology, London, United Kingdom: Academic Press, Ltd., vol. 3A, p. 116, 1970.

[22] R. T. Mandelbaum, D. L. Allan, and L. P. Wackett, "Mineralization of the s-triazine ring of atrazine by stable bacterial mixed cultures," Appl Environ Microbiol, vol. 59, no. 6, pp. 1695-1701, June 1993.

[23] E. Topp, H. Zhu, S. M. Nour, S. Houot, M. Lewis, and D. Cuppels, "Characterization of an atrazine-degrading Pseudaminobacter sp. isolated from Canadian and French agricultural soils," Applied and Environmental Microbiology, vol. 66, no. 7, pp. 2773-2782, July 2000.

[24] J. Sambrook, E. F. Fritsch, and T. Maniatis, "Molecular cloning: A laboratory manual," Cold Spring Harbor Laboratory, New York, p. $545,1989$.

[25] J. D. Thompson, D. G. Higgins, and T. J. Gibson, "CLUSTAL W: Improving the sensitivity of progressive multiple sequence alignment through sequence weighting, position-specific gap penalties and weight matrix choice," Nucleic Acids Res, vol. 22, no. 22, pp. 4673-4680, Nov. 1994.

[26] R. M. Behki and S. U. Khan, "Degradation of atrazine, propazine and simazine by Rhodococcus strain B-30," J. Agric. Food Chem, vol. 42, no. 5, pp. 1237-1241, May 1994.

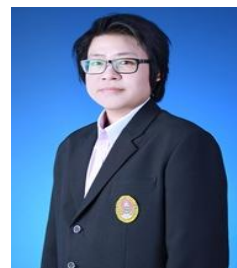

Sopid Sawangjit graduated from the Department of Plant Pathology, Kasetsart University in 1998 for her undergraduate degree, and obtained her doctor degree from the Department of Plant Pathology, Faculty of Agriculture, Kasetsart University in 2005. Her doctoral thesis was "Molecular charac terization of tomato-infecting begomoviruses in thailand". After graduation, she worked as a university lecturer at Suan Sunandha Rajabhat University in 2007. Currently she is working as a university lecturer and the director of Science Center, Suan Sunandha Rajabhat University, and her main topic of research is biodegradation of atrazine. 